\title{
Propagating media affects mango seed germination at different depths
}

\author{
Nadeem Khan ${ }^{1 *}$, Syed Tanveer Shah ${ }^{1}$, Muhammad Sajid ${ }^{1}$, Abdur Rab ${ }^{1}$, \\ Asif Iqbal ${ }^{2}$, Saeed Ul Haq ${ }^{1}$, Mazhar Iqbal ${ }^{3}$, Shahid Rahman ${ }^{1}$, Rafiq \\ $\mathrm{Ahmad}^{4}$, Wajid Ali ${ }^{4}$ and Said Rawan ${ }^{1}$ \\ 1. Department of Horticulture, University of Agriculture, Peshawar,Pakistan \\ 2. Department of Agronomy, University of Agriculture, Peshawar, Pakistan \\ 3. Department of Botany, SBB University Sheringal, Dir Upper, Pakistan \\ 4. Department of SES, University of Agriculture, Peshawar, Pakistan \\ *Corresponding author's email: nadeemaup@yahoo.com \\ Citation \\ Nadeem Khan, Syed Tanveer Shah,Muhammad Sajid, AbdurRab, Asif Iqbal,Saeed UlHaq, Mazhar Iqbal, Shahid \\ Rahman, Rafiq Ahmad, Wajid Ali and Said Rawan. Propagating media affects mango seed germination at different \\ depths. Pure and Applied Biology. Vol. 5, Issue 3, pp392-398. http://dx.doi.org/10.19045/bspab.2016.50051
}

Received: 30/01/2016

Revised: $12 / 04 / 2016$

Accepted: 24/04/2016

Online First: 05/05/2016

\section{Abstract}

An experiment on "Propagating media affects mango seed germination at different depths" was conducted in Jabban, Dargai District Malakand during 2014. Mango seeds were sown in four different propagating media (Farm soil, farm soil+sand+saw dust, farm soil+sand+FYM and farm soil+sand+FYM+saw dust) at three different soil depths $(3 \mathrm{~cm}, 6 \mathrm{~cm}$ and $9 \mathrm{~cm})$. The experiment was conducted using Randomized Complete Block Design (RCBD) with two factors factorial arrangment replicated three times. Days to germination, number of leaves, shoot length and transplantation time were studied during the course of the experiment. The results clearly indicated that propagating media and soil depth significantly influenced all the growth attributes except number of leaves. The mean values for propagating media indicated that minimum days to germination (19.67) and transplantation (27.88) and lengther shoots $(35.22 \mathrm{~cm})$, were observed respectively in seeds grown in Farm soil+Sand+FYM. The data for soil depth also showed that minimum days to germination and transplantation (20.67 and 30.00 respectively), more number of leaves (3.91) and shoot length $(32.23 \mathrm{~cm})$ were obtained from seeds sown at a depth of $3 \mathrm{~cm}$. The interaction between soil depth and propagating media had a non-significant effect on all growth attributes. It is concluded from the present study that seeds should be sown at a depth of $3 \mathrm{~cm}$, grown in Farm soil+Sand+FYM for better results and recommended for the farmers of the agroclimatic condition of Malakand.

Key words:Propagting media; Mango seed; Germination; Soil depth

\section{Introduction}

Mango (Magniferaindica) belongs to the family Anacardiaceae, produces fleshy drupe fruits which are eaten raw, canned, or used for making juices, jams, and other preservations. Mango grows best from sea level to $1400 \mathrm{~m}$ [1-3]. Mango is native of Indian subcontinent but also grown in almost all continents of the world like North, South and Central America, South, West and Central Africa, Australia. It is grown in countries like China, India, Pakistan, 
Bangladesh, Philippine, Burma, Thailand, Malaya, Mexico, Brazil, United States of America, etc. In Asia, it is grown on over 1.0 million ha area and produces over 12.42 million tons per year [4]. Single trees can produce between 200 and $300 \mathrm{~kg}$ (440$660 \mathrm{lb}$ ) of fruit in heavy cropping years and as low as $5 \mathrm{~kg}$ in bad years [5]. In Pakistan mango is not only a source of employment in the countryside, but is also an important foreign currency earning fruit. It is grown in various southern districts of Sindh, Pakistan such as; Hyderabad, TandoAllahyar, Matiary, Mirpur Khas, Sanghar and Nawabshah. Several commercial varieties of mango are popular in these districts which are exported to generate foreign earnings [4]. Mango tree needs deep and well drained, and slightly acidic soil with moderate water holding capacity and light slope for drainage [1].Germination of the seed is a critical stage, because rest of the plant life is directly dependent upon the rate of its germination [6]. Soil media play a key role in enhancing soil physical and chemical properties and thereby increasing the penetrating capacity of roots in silt+clay media. When suitable environment with proper aeration, sufficient water and nutrient availability was offered by the medium, excellent roots system developed which in turn result the luxurious growth of plants [7]. The tendency to supply all plant nutrients through chemical fertilizers should be reconsidered now or in the future because this has a deleterious effect on soil productivity on a long term basis [8]. Seed germination is influenced by many factors such as the type of substrate used, environmental factors such as oxygen, water, temperature and for some plant species, light [9]. Generally, growth medium has been declare to be the most critical factor determining seedling quality in the nursery [10], acting as a reservoir for nutrients and moisture [11]. Apart from medium, physical properties can also have a profound effect on the supply of water and air to the growing plant [12]. The soil depth available for rooting is a major physical soil factor in silviculture [13]. Shallowness of the soil limits its utilization by restricting the supply of moisture, air and nutrients available to the forest stand and thus reduction of stand availability. [14] reported that several compost media tested were found best for plant growth, aeration, good moisture retention and suitable nutrient retention, thus depths at which seeds are sown into the soil affect the germination of these seeds, and subsequent by seedling growth [15]. Some seeds germinate well on the soil surface while others require a little or more depth into the soil. The sizes of the seeds also play a major role on the emergence of the seedlings and growth. Large seeds produce larger seedlings than small ones, hence are able to emerge from greater soil depths [16, 17] observed that large robust seedlings emerged and that seedling emergence through litter is positively associated with seed size.However, a thumbs rule of is that to sow seeds approximately three to four times the diameter of the seed, making sure that seeds are in the upper moist layer of the soil [18]. On the other hand, [19] stated that sowing depth is generally twice the diameter of the seed.In nursery production industry, a variety of propagating media and soil depth are in use worldwide. Growers and nurserymen in Pakistan, specifically of Khyber Pakhtunkhwa, are not familiar with the propagation of mango seeds. To solve this problem, the current experiment was designed with different planting media and soil depthas the planting medium and depth is considered to be an important and necessary factor for the growth and development of a plant. It provides the basic necessities required by a plant throughout its life. In general, rooting through layering in various types of soil environments influence rooting significantly due to physical and 
chemical properties of the media having a $\mathrm{pH}$ range conducive to plant growth, that permit gaseous exchange to provide aeration for the roots and permits water infiltration and its movement .

\section{Materials and methods}

The research study "Propagating media affects mango seed germination at different depths" was conducted in the Government Fruit Nursery Farm,Jabban, Dargai District Malakandduring 2014. Fresh mature and healthy depulped seeds of mango varietyChonssa were obtained from the same Nursery.Seeds are best collected from fully mature or ripe fruits before the fruits have begun to decay with postharvestdiseases. Seeds from the larger fruits generally produce the most vigorous seedlings. The experiment was conducted using Randomized Complete Block Design (RCBD) with two factors factorial arrangmentwith twelve treatment combinations replicated three times.The mango seed were sown in four different propagating media (Farm soil, Farm soil+sand+saw dust, Farm soil+sand+FYM and Farm soil+sand+FYM+saw dust) at three different soil depths $(3 \mathrm{~cm}, 6 \mathrm{~cm}$ and $9 \mathrm{~cm})$.Prepare the land through spade's before sowing the seeds. Remove weeds, plastics, stones, pebbles etc by hand and level the land. Seeds were collected from a mature fruit tree and seed were extrected through knife with hand. Sow the seed with a distance of $20 \mathrm{~cm}$ seed to seed and $30 \mathrm{~cm}$ row to row. First irrigation was done at the time of sowing and then after irrigate the field four days intervel.

\section{Selection of the Media}

Saw dust, silt, garden soil and their mixture was used, before using media it was confirmed that these were free of pathogens, weeds, pests, nematodes, have good water holding capacity and good drainage. Mango seed germination was done in June on different soil depth $(3 \mathrm{~cm}, 6 \mathrm{~cm}$ and $9 \mathrm{~cm})$ in different media (Farm soil, Farm soil+sand+saw dust, Farm soil+sand+FYM and Farm soil+sand+FYM+saw dust).

The following parameters were studied during the course of the study.

\section{Days to germination}

Numbers of days from the date of sowing to germination were counted for each treatment in each replication and their average was calculated.

\section{Transplanting time}

Transplanting time were recorded for each traetment in each replication when the seed were fully changed into roots and their average was calculated.

\section{Numbers of leaves}

Numbers of leaves of five randomly selected plants were counted for each treatment in each replication, at the time when the color of leaves turned from brown to green and their average was calculated.

\section{Shoot length (cm)}

Shoot length were taken after one month with the help of measuring tape for each treatment in each replication from the soil surface to the shoot tip and their average was calculated.

\section{Statistical analysis}

The data recorded on different parameters were analyzed by using the statistical computer software, MSTATC (Michigan state university, USA). Analysis of variance (ANOVA) and LSD test were performed to find out the differences between treatments and interaction. The mean values for difference were compared by using Least Significant Difference (LSD) Test [20].

\section{Results and discussion} Germination time

Germination time of mango seeds were significantly affected by soil depthand growing mediawhere as their interaction was found non-significant (Table 1). The mean data table indicates that early germination (20.67) of mango was recorded in seeds sown at a depth of $3 \mathrm{~cm}$, which was at par with germination time (21.50) at a seed depth of $6 \mathrm{~cm}$. While late germination (22.33) was 
observed in seed depth at $9 \mathrm{~cm}$.As regarding propagating media, counting more number of days to germination (22.79) was recorded in seed sown in propagating media Farm soil+sand+saw dust, which was statistically similar with mean germination time (22.11) in seed sown in control media i.e. propagating media Farm soil. While less days to germination (19.67) was observed in propagating media Farm soil+sand+FYM. The differences among the soil depth might be due to the facts that the seeds in depth of $3 \mathrm{~cm}$ absorbed more water, it loose the seed coat and activate the enzyme gibbrellic acid, cause seed germination and suppress the growth of abcessic acid and then seeds immediately began to germinate. The water still had not penetrated deeply in the soil. Water may gradually infiltrate into the soil and reaches greater depths and availability of water increases at this depth [21]. Early germination in Farm soil+Sand+FYM due to propagating media containing organic manures that possessed organic acid within them. Therefore, more available moisture and some acids might helped in minimum days to germination and better germination percentage [22]. Similar results were reported by [23] in ber (Zizyphus mauritiana).

Table 1. Germination time, transplantation time, number of leaves and shoot length $(\mathrm{cm})$ of mango seed as affected by different propagating media at different soil depth

\begin{tabular}{lcccc} 
& \multicolumn{3}{c}{ Parameter } \\
\cline { 2 - 5 } Depth $(\mathbf{c m})$ & $\begin{array}{c}\text { Germination } \\
\text { time }\end{array}$ & $\begin{array}{c}\text { Transplantation } \\
\text { time }\end{array}$ & $\begin{array}{c}\text { Number of } \\
\text { leaves }\end{array}$ & $\begin{array}{c}\text { Shoot } \\
\text { length }(\mathbf{c m})\end{array}$ \\
\hline 3 & $20.66 \mathrm{a}$ & $30 \mathrm{a}$ & 3.91 & $32.33 \mathrm{a}$ \\
6 & $21.5 \mathrm{ab}$ & $31.33 \mathrm{ab}$ & 3.83 & $30.25 \mathrm{ab}$ \\
9 & $22.33 \mathrm{~b}$ & $33 \mathrm{~b}$ & 3.58 & $28.75 \mathrm{~b}$ \\
\hline LSD $_{0.05}$ & 1.13 & 1.97 & $\mathrm{~ns}$ & 2.85 \\
\hline Propagating media & & & & \\
Farm soil (FS) & $22.11 \mathrm{ab}$ & $32.44 \mathrm{ab}$ & $3.88 \mathrm{ab}$ & $29.66 \mathrm{~b}$ \\
FS+Sand+Sawdust & $22.79 \mathrm{c}$ & $34.33 \mathrm{c}$ & $3.44 \mathrm{ab}$ & $27.33 \mathrm{~b}$ \\
FS+Sand+FYM & $19.67 \mathrm{a}$ & $27.88 \mathrm{a}$ & $4.11 \mathrm{a}$ & $35.22 \mathrm{a}$ \\
FS+Sand+FYM+Saw & & & & \\
dust & $21.44 \mathrm{~b}$ & $31.11 \mathrm{~b}$ & $3.66 \mathrm{~b}$ & $29.55 \mathrm{~b}$ \\
\hline LSD 0.05 & 1.31 & 2.28 & 0.46 & 3.29 \\
\hline Interaction & & $\mathrm{ns}$ & $\mathrm{ns}$ & $\mathrm{ns}$ \\
(DxM)LSD 0.05 & $\mathrm{~ns}$ & &
\end{tabular}

Means followed by similar letters are statistically non-significant / similar at $5 \%$ level of significance

\section{Transplantation time}

The data for transplantation time shows that soil depth and propagating media significantly influence the transplantation time of mango seedling where as their interaction was found non-signifacant (Table-1). The mean data table indicates that early transplantation time (30.00) of mango was recorded in seed sown at a depth of $3 \mathrm{~cm}$, which was at par with transplantation time (31.33) at a seed depth of $6 \mathrm{~cm}$. while late transplantation of mango seedling (33.00) was observed in seed depth at $9 \mathrm{~cm}$.As regarding propagating media the early transplantation of mango seedling (27.88) was recorded in seed sown in propagating media Farm soil+sand+FYM. While late transplantation time (34.33) was observed in propagating media Farm soil+sand+saw dust. In this way, nursery cultivation regimes can strongly determine the functional characteristics of seedlings and their field 
performance [21], giving the possibility to produce seedlings better adapted to special environmental conditions and thus increasing transplanting success.It has been established that addition of natural organic manure could change media properties by effects of thermal heating on soil microbiota resulting in steam induced changes in soil chemical properties, and help in vigorous growth and development of plant [24]. It has been reported that steam sterilized fresh manure reduced accumulation of toxic substances in the media leading to better plant growth and root mass in citrus and avocado [25].

\section{Number of leaves}

Data regarding number of leaves shows that propagating media significantly influence the number of leaves of mango seedling whereas soil depth and their interaction was found non-signifacant (Table-1).As regarding propagating media, more number of leaves (4.11) was recorded in seed sown in propagating media Farm soil+sand+FYM, which was statistically similar was number of leaves (3.88 and 3.44) in seed sown in propagating media Farm soil and propagating media Farm soil+sand+saw dust respectively. While less number of leaves (3.66) was observed in propagating media Farm soil+sand+FYM+saw dust. This might be attributed to the general improvement in nutrient availability leading to higher production of photosynthetically functional leaves [26]. The present results are in conformity with those reported by [27] in silk cotton (Ceibapentandra L.).

\section{Shoot length (cm)}

The data for Shoot length $(\mathrm{cm})$ shows that soil depth and propagating media significantly influence the Shoot length $(\mathrm{cm})$ of mango seedling where as their interaction was found non-signifacant (Table-1).The mean data Table indicates that highest shoot length $(32.33 \mathrm{~cm})$ of mango was recorded in seed sown at a depth of $3 \mathrm{~cm}$, which was at par with shoot length $(30.25 \mathrm{~cm})$ at a seed depth of $6 \mathrm{~cm}$. while lowest shoot length $(28.75 \mathrm{~cm})$ was observed in seed depth at $9 \mathrm{~cm}$.As regarding propagating media, highest shoot length $(35.22 \mathrm{~cm})$ was recorded in seed sown in propagating media Farm soil+sand+FYM. While lowest shoot length $(27.33 \mathrm{~cm})$ was observed in propagating media Farm soil+sand+saw dust, which was statistically similar was shoot length $(29.55 \mathrm{~cm}$ and $29.66 \mathrm{~cm})$ in propagating media Farm soil+sand+FYM+saw dust with and Farm soil. This may be attributed to general improvement inhigher water and nutrient availability for seedling growth [28]. The vigorous and fast growth of seedlings may be attributed to better water holding capacity and availability of nutrients for plant growth [29]. Similar results were obtained by [21] in field bindweed (Convolvulus arvensis L.). This may be attributed to general improvement in the physical and chemical properties of the rooting medium [30] in Chilgoza pine. Similar results were obtained by [27] in silk cotton (Ceibapentandra Linn.), [31] in bewal (Griwiaoptiva burrett) seedlings [32] in arnotta plant (Bixaorellana) [33].

\section{Conclusion and recommendation}

It is concluded from the study that mango seed should be best sown in Farm soil+Sand+FYM in all respect e.g. days to germination, shoot length, number of leaves and transplantation time as compared to other propagating media (Farm soil, Farm soil+sand+saw dust, Farm soil+Sand+FYM+saw dust).As regards different soil depth, seeds sown at $3 \mathrm{~cm}$ depth give early germination, transplantation time and shoot length, where number of leaves was not affected by soil depth. Therefore Farm soil+Sand+FYM and seeds should be sown at a depth of $3 \mathrm{~cm}$ performed better for all the attributes hence recommended for better seed germination of mango for the agro-climatic condition of Malakand.

\section{Authors' contribution}


Conceived and designed the experiments: ST Shah, Performed the experiments: M Sajid, A Rab \& N Khan, Analyzed the data: R Ahmad, M Iqbal \& W Ali, Contributed reagents/materials/analysis tools: A Iqbal, $\mathrm{S}$ Rawan, SU Haq \& S Rahman, Wrote the paper: N Khan.

\section{References}

1. Aduayi EA (1980). Effect of ammonium sulphate fertilization on soil chemical composition, fruit yield, and nutrient content of okra. J Agric 2(1): 16-33.

2. Agbede OO \& Kalu BA (1990). An assessment of fertilizer use under traditional cropping systems in the middle belt zone of Nigeria. In: Proceedings of the third national farming system research network workshop. Research Network Workshop. University of Calabar, Nigeria. pp. 15-16.

3. Obi ME \& Ofonduru CO (1997). The effects of soil amendments on soil physical properties of a severely degraded sandy loam soil in South Eastern Nigeria. In: Proceedings of twenty-fourth annual conference Soil Science Society of Nigeria "The national conference on soil management for food security". Usman Danfodio University, Sokoto, Nigeria. Pp. 30-35.

4. Chadha KL \& Pal RN (1993). The current status of the mango industry in Asia. IV International Mango Symposium. ISHS Acta Horticulturae 341. Available in ActaHort CD-rom format only.

5. Bally ISE (2006). Mangiferaindica (Mango), ver. 3.1. In: Elevitch CR (ed.). Species Profiles for Pacific Island Agroforestry. Permanent Agriculture Resources (PAR), Hōlualoa, Hawaii. http://www.traditionaltree.org.

6. Qadir SA \& Shahzadi HN (1969). Seed germination of common cultivated trees, shrubs and some wild grass. Pakistan $J$ Forestry 19: 195-220.

7. Neelam A \& Ishtiaq M (2001). Response of Eucalyptus camaldulensis seedlings to different soil media. Sarhad J Agri 17(1): 75-79.

8. Yadav RL \& Prassad SR (1992). Conserving the organic matter content of soil to sustain sugarcane yield. Expl Agri 28: 51-62.

9. Hartmann HT, Kester DE, Davies FT \& Genve RI (2007). Hartmann and Kester's plant propagation, principles and practices. Seventh edition. Prentice-Hall of India Private limited. Pp. 880.

10. Baiyeri KP\&Mbah BN (2006). Effects of soilless and soil based nursery media on seedling emergence, growth and response to water stress of African breadfruit (Treculia Africana Decne). Afri J Biotech 5: 1405-1410.

11. Grower ST (1987). Relations between mineral nutrient availability and fine root biomass in two Costa Rican tropical wet forests. Hypothesis Biotropica 19: 171175.

12. Baiyeri KP (2005). Response of musa species to macro-propagation and the effects of genotype, initiation and weaning media on sucker growth and quality in the nursery. Afric J Biotech 4(3): 229-234.

13. Nwoboshi LC (1982). Tropical Silviculture, Principles and Techniques, Department of Forest Res. Mgt., University of Ibadan, Nigeria. University Press. pp. 333.

14. Wootton RD, Gouin FR\& Stark FC (1981). Composted, Disgested sludge as a medium for flowering annuals. J Ameri Soc Hort Sci 106(1): 46-49.

15. Bockus WW \& Sholberg JP (1996). Effect of seed size on seedling vigour and forage production of winter wheat. Canad J Plant Sci 76: 101-105.

16. Jurik TW, Wang SC \& Vanderwalk AG (1994). Effects of sediment load on seedling emergence from wetland banks. Wetlands 14: 159-165.

17. Seiwa K \& Kikuzawa K (1996). Importance of seed size for the establishment of seedlings of five deciduous broad-leaved tree species. Vegetation 123: 51-64.

18. Hudson TH \& Dale EK (1975). Plant propagation: Principles and Practices 3rd 
Edition, Prentice-Hall. Pp. 662. Amason, USA.

19. Harries, Peter $P$ \& Erik S (1998). Propagating and planting trees. Agrodok Series. Hartmann HT, Kester DE \& Davies FT (1990). Plant Propagation: Principles and Practices. 5th ed. Regents/Prentice Hall, Inc., Englewood Cliff. New Jersey. Pp. 73.

20. Steel RGD, Torriea JH \& Dickey DA (1997). Principle and procedure of statistic. A biometrical approach, 3rd ED. MCGRAW Hill Book Co. Inc. New York. Pp.172-177.

21. Asgharipour (2011). Effects of planting depth on germination and the emergence of field bindweed (Convolvulus arvensis L.). Asian J AgricSci 3(6): 459-461.

22. Bisla SS, Singhrot RS \& Chauhan SS (1984). Effect of growing media on seed germination and growth of Ber. Haryana $J$ Hort Science 13(3-4): 118-122.

23. Shergill TS, Singh H\&Mehrotra NK (1992). Evaluation of different ber (Ziziphusmauritiana) varieties for raising rootstock. Punjab Horticulture 32(1-4): 88-91.

24. Gelsomino A,Petrovicova B, Zaffina F \& Peruzzi A (2010). Chemical and microbial properties in a greenhouse loamy soil after steam disinfestation alone or combined with $\mathrm{CaO}$ addition. Soil Biol\&Biolchemestry 42:1091-1100.

25. Allan P, Lamb D, Chalton D \& Chalton D (1981). Sterilization and pasteurization of soil mixes. S. African Avocado Growers Assoc. Year book 4: 124-127.

26. Borah AS,Nath A, Ray AK, Bhat R, Maheswarappa HP, Subramanian P,
Dileep M, Sudhakara K, Santhoshkumar AV, Nazeema KK \& Ashokan PK (1994). Effect of seed size, rooting medium and fertilizers on the growth of seedlings of silk cotton (Ceibapentandra L.). Indian J of Forestry 17(4): 293-300.

27. Sudhakara K, Mammen W, Santoshkumar AV \& Ashokan PK (1995). Effect of seed size, IndianForestery 21(12): 1135-1142.

28. Timmer VR \&Armstrong G (1989). Growth and nutrition of containerized Pinusresinosa seedlings at varying moisture regimes. New Forest 3: 171-180.

29. Hafeez-ur-Rahman, Rafiq M, Nabi G\&Samad A (2007). Effect of soil media on peach seed germination and seedling growth in climatic conditions of OrakzaiAgency (FATA). Sarhad JAgri 23(3): 689-691.

30. Shamet GS, Chauhan PS \& Sood R (1994). Nursery studies on potting mixture, mulching and fertilizer requirements of chilgoza pine (Pinusgerardiana Wall). Indian J Forestry 17(3): 225-229.

31. Nayital RK, Sharma DP\& Varma KS (1995). Growth performance of bewal (GriwiaoptivaBurrett) seedlings in different growing media. Indian J Forest. 18(3): 239-241.

32. Nelson K, Srimathi P \&Ponnuswamy AS (2008). Influence of potting mixture on elite seedling production in arnotta plant (Bixaorellana). Madras JAgri 95(7-12): 496-498.

33. Radhakrishnan B \& Mahendran P (2010). Effect of vermicompost and vermiwash on growth and development of tea. $J$ Plantation Crops 38(1): 27-31. 